\title{
The Impact of Serum Creatinine, Albumin, Age, and Gender on the Development of Contrast- Induced Nephropathy in Patients Exposed to Contrast Agent Upon Admission to the Emergency Department
}

\author{
Canan Akman ${ }^{1}$, Serkan Bakirdogen ${ }^{2}$ \\ 1. Emergency Department, Çanakkale Onsekiz Mart University Faculty of Medicine, Canakkale, TUR 2. Nephrology \\ Department, Çanakkale Onsekiz Mart University, Canakkale, TUR
}

Corresponding author: Canan Akman, drcananakman@gmail.com

\section{Abstract}

\section{Background and objectives}

As the stage progresses in chronic kidney disease (CKD), the risk of contrast-induced nephropathy (CIN) also increases. Serum albumin level is the strongest predictor of CIN development in patients with CKD. It is widely known that females of age 75 are at risk for the development of CIN. Our study aims to investigate the impact of age, gender, serum creatinine, and albumin levels on the development of CIN in patients who were admitted to the emergency department and have had contrast-enhanced computerized tomography (CECT) for diagnosis.

\section{Materials and methods}

The study was planned retrospectively. Patients who applied to the emergency department between January 1,2018 , and January 1, 2020, and had CECT were included in the study. A $25 \%$ or $0.5 \mathrm{mg} / \mathrm{dL}$ increase in serum basal creatinine level within 72 hours following the implementation of contrast agent was accepted as CIN. The patients were divided into two groups: CIN (+) and CIN (-).

\section{Results}

One-hundred twenty-two patients ( 53 female and 69 male), whose average age was $72.27 \pm 12$, were included in the study. Forty-five of the patients were found to be CIN $(+)$ and 77 CIN (-). There was no significant difference between the groups ( $p>0.05$ ) in terms of age. It was found that the serum creatinine level during admission to the emergency department was the determinant for the development of CIN $(p=0.024)$. In addition, it was observed that serum albumin levels during the admission had no impact on the development of $\operatorname{CIN}(p=0.326)$. When the serum albumin values of female and male patients diagnosed with CIN measured at the first admission to the emergency service were compared, the mean values were found to be lower in male patients $(\mathrm{p}=0.027)$.

Review began 10/05/2020 Review ended 10/14/2020 Published 10/20/2020

\section{๑) Copyright 2020}

Akman et al. This is an open access article distributed under the terms of the Creative Commons Attribution License CC-BY 4.0., which permits unrestricted use, distribution, and reproduction in any medium, provided the original author and source are credited.

\section{Conclusion}

Serum creatinine and albumin levels, age, and gender parameters should be considered in terms of the risk of CIN development in patients who are admitted to the emergency department and given contrast agents.

Categories: Emergency Medicine, Nephrology

Keywords: age, gender, creatinine, albumin, contrast induced nephropathy

\section{Introduction}

Contrast-induced nephropathy (CIN) is an acute kidney injury (AKI) that develops upon using a contrast agent. CIN is defined as an increase in the level of serum basal creatinine over $25 \%$ or $0.5 \mathrm{mg} / \mathrm{dL}$ within 72 hours of exposure to a contrast agent. A contrast agent can cause renal ischemia and direct tubulus toxicity [1-2]. CIN is the third most common cause of hospital-acquired AKI, with a frequency of $10 \%$ [3]. As the stage progresses in chronic kidney disease (CKD), the risk of CIN also increases. There are many factors that contribute to the pathogenesis of CIN [4]. The serum albumin level is the strongest predictor of CIN development in patients with CKD [5]. The serum albumin level of the patients who developed CIN after exposure to the contrast agent was found to be lower than the ones without contrast nephropathy [6]. The literature shows that the female gender is a risk factor for the development of CIN [7-8]. In addition, being over 75 years of age is an independent risk factor for the development of CIN [2]. In our study, we aimed to investigate the impact of the parameters of age, gender, serum creatinine, and albumin levels on the development of CIN in patients admitted to the emergency department and exposed to a contrast agent. 


\section{Materials And Methods}

Our study was planned retrospectively. After the approval of the Local Ethical Committee (Reference number: 2020-09), among 941 patients who applied to the emergency service of the Health Practice and Research Hospital between January 1, 2018, and January 1, 2020, 122 patients aged 18 and over who had contrast-enhanced computerized tomography (CECT) were included in the study. The exclusion criteria of the study were determined as follows: being under the age of 18 , the diagnosis of chronic renal failure, hemodialysis or peritoneal dialysis, serum creatinine level above $4 \mathrm{mg} / \mathrm{dL}$, and incomplete medical records of the patient. A $25 \%$ or $0.5 \mathrm{mg} / \mathrm{dL}$ increase in serum basal creatinine level within 72 hours following the implementation of a contrast agent was accepted as CIN [1-2]. The patients were divided into two groups: CIN (+) and CIN (-).

The serum creatinine, urea, albumin, calcium, and uric acid levels of the patients were analyzed using the colorimetric method in the Roche Cobas 6000-501 module (Roche Diagnostics, Basel, Switzerland). An ionselective electrode (ISE) and potentiometric method were used in the analysis of ionized calcium in the biochemistry laboratory using Radiometer ABL 800 (Copenhagen, Denmark).

Since the biochemistry data of patients with and without CIN and patients with different gender did not show normal distribution ( $\mathrm{p}<0.05$ ), they were compared using the Mann-Whitney $U$ test. When the patients were admitted to the emergency service, their serum creatinine, urea, albumin, uric acid, calcium, and ionized calcium levels were determined. The same levels were reevaluated 72 hours after contrast agent administration. Therefore, the levels of the groups with and without CIN at the time of admission to the emergency department and after 72 hours were tested using the Wilcoxon signed-rank test. The ages of the groups with and without nephropathy were compared after contrast agent administration. Since the ages showed a normal distribution, it was compared using the student's t-test. The distribution of patients with and without CIN after contrast agent according to the gender variable was compared using the chi-square test. Multinomial logistic regression was applied to determine the impact of biochemistry results on gender groups and on whether diagnosed with CIN or not. $\mathrm{p}<0.05$ was used for statistical significance. The Statistical Package for the Social Sciences (SPSS) version 19.0 (IBM Corp, Armonk, NY) was used in the analysis.

\section{Results}

One hundred twenty-two patients ( 53 female and 69 male) were included in the study. The average age of the patients was found to be $72.27 \pm 12$. After CECT, 45 patients were determined as CIN (+) and 77 as CIN (). CIN developed in 45 patients (13 female and 32 male). There was no significant difference between the groups in terms of age $(p>0.05)$. However, a significant difference was found in terms of gender $(p=0.013)$. In the examinations performed after contrast agent administration, serum creatinine, urea, albumin, uric acid, calcium, and ionized calcium levels were compared in CIN (+) and CIN (-) groups during admission to the emergency department and 72 hours after contrast agent were administered. The results are shown in Table 1 . When the patients included in the study were evaluated according to their comorbidity, hypertension $(n=29)$, malignancy $(n=25)$, and coronary artery disease $(n=9)$ were the top three among the illnesses. A comparison of the patient groups in terms of age is shown in Table 2 and the comparison of gender distributions in Table 3. Gender, diagnosis of CIN after contrast agent administration, first admission to the emergency room, and biochemistry results obtained at 72 hours after contrast agent were analyzed with comparison tests. Multinomial logistic regression was applied using variables with significant results in these comparison tests. In the regression analysis, the male patient group with CIN was taken as the reference. The comparisons were interpreted according to this group. Being a male and having a high serum creatinine level increased the risk of being diagnosed with CIN approximately one-fold as compared to being a female patient and having a low serum creatinine level $(\operatorname{Exp}[\mathrm{B}]=1.148)$. Similarly, being a female and being older increased the risk of being diagnosed with CIN approximately one-fold as compared to being male and being at a younger age (Exp $[\mathrm{B}]=1.113)$. Furthermore, being a female patient and having a high pre-contrast serum albumin level increased the risk of being diagnosed with CIN nearly four times as compared to being a male and having a low pre-contrast serum albumin level (Exp $[B]=4.362)$. Multinomial logistic regression analysis in patient groups is given in Table 4. Chi-square test results showed that there was a difference in the gender distribution of CIN $(+)$ and $\operatorname{CIN}(-)$ patients after contrast agent administration $(p<0.05)$. This difference was obtained at a small effect size $(\phi c=0.22)$. In the chi-square test, the differences between the groups were compared. The percentage of female patients is higher in the CIN (-) group, whereas the percentage of males in the CIN $(+)$ group is higher. It was found that the serum creatinine level at the time of admission was a determinant of the development of CIN $(p=0.024)$. It was also found that serum urea, albumin, uric acid, corrected calcium and ionized calcium levels during admission to the emergency department had no impact on the development of CIN ( $p>0.05)$. The comparison of serum albumin and creatinine levels between the CIN (+) and CIN (-) groups before contrast agent administration is shown in Table 5 and the comparison of serum albumin levels measured at the first admission to the emergency service of female and male patients diagnosed with CIN is given in Table 6 . 


\section{Cureus}

\begin{tabular}{|c|c|c|c|c|}
\hline Group & Variable & $\begin{array}{l}\text { Mean I(Standard Deviation) / Mean II (Standard } \\
\text { Deviation) }\end{array}$ & $\begin{array}{l}\text { Med }_{1}(\text { Min-Max) / Med II }(\text { Min- } \\
\text { Max) }\end{array}$ & P \\
\hline \multirow{6}{*}{$\begin{array}{l}\mathrm{CIN}(-) \\
(\mathrm{N}=77)\end{array}$} & Creatinine (mg/dL) & $0.95 \pm 0.31 / 0.79 \pm 0.28$ & $0.93(0.38-1.65) / 0.74(0.28-1.46)$ & $<0.0001$ \\
\hline & Urea (mg/dL) & $45.24 \pm 23.08 / 39.69 \pm 23.69$ & $40.0(10.6-139.0) / 34.4(2.8-138.1)$ & $<0.0001$ \\
\hline & Uric acid (mg/dL) & $5.90 \pm 2.18 / 5.37 \pm 2.33$ & $5.9(2.2-13.2) / 4.8(2.1-15.4)$ & 0.004 \\
\hline & $\begin{array}{l}\text { Corrected Calclum } \\
(\mathrm{mg} / \mathrm{dL})\end{array}$ & $9.23 \pm 0.84 / 9.20 \pm 0.75$ & $9.31(5.8-13.4) / 9.14(7.8-14.1)$ & 0.400 \\
\hline & lonized calcium (mmol/L) & $1.13 \pm 0.08 / 1.11 \pm 0.08$ & 1.12(0.87-1.58)/ 1.12(0.83-1.33) & 0.076 \\
\hline & Albumin (g/dL) & $3.60 \pm 0.68 / 3.13 \pm 0.62$ & $3.63(1.81-5.2) / 3.10(1.55-4.65)$ & $<0.0001$ \\
\hline \multirow{6}{*}{$\begin{array}{l}\mathrm{CIN}(+) \\
(\mathrm{N}=45)\end{array}$} & Creatinine (mg/dL) & $1.15 \pm 0.48 / 1.57 \pm 0.85$ & $1.04(0.48-3.09) / 1.39(0.63-4.79)$ & $<0.0001$ \\
\hline & Urea (mg/dL) & $53.4 \pm 28.9 / 77.7 \pm 46.8$ & $\begin{array}{l}49.5(8.30-1 / 9.4) / 66.6(20.2- \\
229.0)\end{array}$ & $<0.0001$ \\
\hline & Uric acid (mg/dL) & $5.85 \pm 2.43 / 6.15 \pm 2.73$ & $5.20(2.0-11.6) / 5.50(2.20-13.40)$ & 0.112 \\
\hline & $\begin{array}{l}\text { Corrected calcium } \\
(\mathrm{mg} / \mathrm{dL})\end{array}$ & $9.38 \pm 0.59 / 9.25 \pm 0.75$ & $\begin{array}{l}9.48(7.77-10.97) / 9.27(7.03- \\
12.27)\end{array}$ & 0.138 \\
\hline & Ionized calcium (mmol/L) & $1.13 \pm 0.08 / 1.10 \pm 0.10$ & $1.13(0.96-1.38) / 1.10(0.86-1.40)$ & 0.123 \\
\hline & Albumin (g/dL) & $3.44 \pm 0.75 / 3.17 \pm 0.72$ & $3.52(1.61-5.19) / 3.27(1.56-4.34)$ & 0.002 \\
\hline
\end{tabular}

TABLE 1: Comparison of the biochemistry results of the patient groups before (I) and after (II) contrast agent

CIN: contrast-induced nephropathy

\begin{tabular}{|c|c|c|}
\hline Group & Mean (SD) & p \\
\hline CIN (-) & $71.10 \pm 11.83$ & \multirow{2}{*}{0.161} \\
\hline CIN (+) & $74.27 \pm 12.19$ & \\
\hline CIN: cont & & \\
\hline
\end{tabular}




\section{Cureus}

\begin{tabular}{|c|c|c|c|c|c|c|}
\hline & & \multicolumn{2}{|l|}{ Gender } & \multirow{2}{*}{ Total } & \multirow{2}{*}{$\mathbf{p}$} & \multirow{2}{*}{ Effect Size $\left(\phi_{c}\right)$} \\
\hline & & Female & Male & & & \\
\hline \multirow{3}{*}{ CIN (-) } & $\mathrm{F}$ & 40 & 37 & 77 & \multirow{6}{*}{0.013} & \multirow{6}{*}{0.22} \\
\hline & \% Contrast-induced nephropathy & 51.9 & 48.1 & 100 & & \\
\hline & $\%$ Gender & 75.5 & 53.6 & 63.1 & & \\
\hline \multirow{3}{*}{ CIN (+) } & $\mathrm{F}$ & 13 & 32 & 45 & & \\
\hline & $\%$ Contrast-induced nephropathy & 28.9 & 71.1 & 100 & & \\
\hline & \% Gender & 24.5 & 46.4 & 36.9 & & \\
\hline
\end{tabular}

TABLE 3: Comparison of the gender distributions of patient groups

CIN: contrast-induced nephropathy

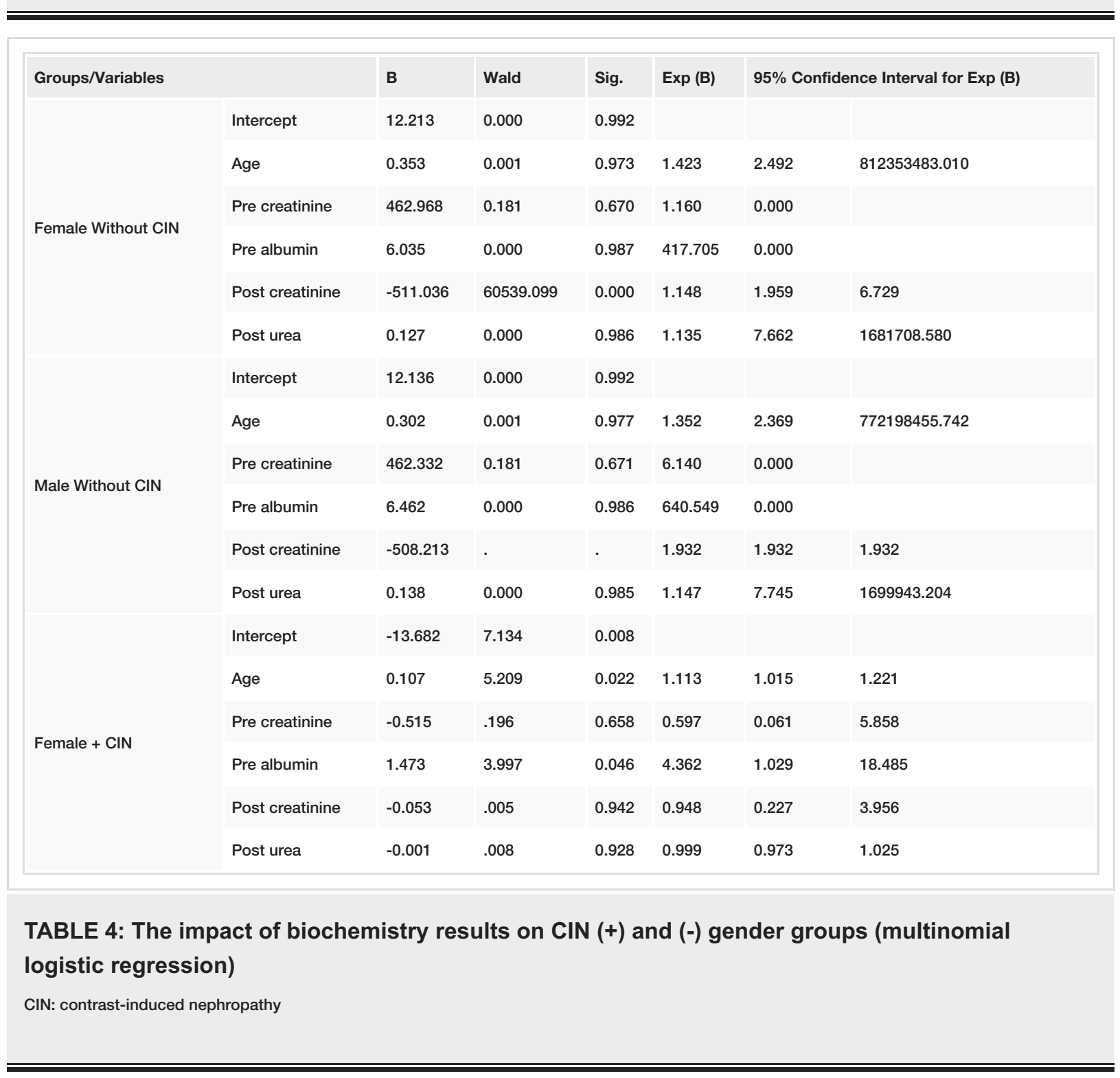




\section{Cureus}

\begin{tabular}{|c|c|c|c|c|c|c|c|c|}
\hline & \multicolumn{4}{|c|}{ State of Diagnosis Upon Contrast } & $\mathbf{N}$ & Mean (SD) & Median (Min-Max) & $\mathbf{p}$ \\
\hline \multirow{2}{*}{ Creatinine (mg/dL) } & \multicolumn{4}{|c|}{ Without CIN } & 77 & $0.95(0.31)$ & $0.93(0.38-1.65)$ & \multirow{2}{*}{0.024} \\
\hline & \multicolumn{4}{|c|}{ With CIN } & 45 & $1.15(0.48)$ & $1.04(0.48-3.09)$ & \\
\hline \multirow{2}{*}{ Albumin $(\mathrm{g} / \mathrm{dL})$} & \multicolumn{4}{|c|}{ Without CIN } & 77 & $3.60(0.68)$ & $3.63(1.81-5.20)$ & \multirow{2}{*}{0.326} \\
\hline & \multicolumn{4}{|l|}{ With CIN } & 45 & $3.44(0.75)$ & $3.52(1.61-5.19)$ & \\
\hline \multicolumn{9}{|c|}{$\begin{array}{l}\text { TABLE 5: Comparison of serum albumin and creatinine levels between the CIN (+) and CIN (-) } \\
\text { groups before the administration of contrast agent } \\
\text { CIN: contrast-induced nephropathy }\end{array}$} \\
\hline & & Gender & $\mathbf{N}$ & Mean (SD) & & Media & in-Max) & p \\
\hline \multirow{2}{*}{ Albumin (g/dL) Level } & & Female & 13 & $3.82(0.66)$ & & $3.94(2$ & 5.19) & \multirow{2}{*}{0.027} \\
\hline & & Male & 32 & $3.28(0.74)$ & & $3.33(1$ & 4.38) & \\
\hline
\end{tabular}

TABLE 6: Comparison of the serum albumin levels of female and male patients diagnosed with $\mathrm{CIN}$ at the first admission to the emergency department

CIN: contrast-induced nephropathy

\section{Discussion}

The risk of CIN increases as the stage progresses in CKD [4]. As the glomerular filtration rate (GFR) drops below $60 \mathrm{~mL} / \mathrm{min} / 1.73 \mathrm{~m}^{2}$, the incidence of CIN increases [9]. In our study, we observed that the average serum creatinine level of the patients with CIN (+) was higher than that of patients with CIN (-). The serum creatinine levels of patients with CIN (+) at the $72^{\text {nd }}$ hour were higher than the levels at admission to the emergency department, and there was a significant difference between the levels. The fact that the serum creatinine levels at the $72^{\text {nd }}$ hour in patients with CIN (-) are lower than the levels at the time of admission may be due to the parenteral fluid support administered in the emergency service.

The serum albumin level is the strongest predictor of the development of CIN in patients with CKD [5]. The serum albumin level of the patients who developed CIN after exposure to a contrast agent was found to be lower than the level of the patients without CIN [6]. In our study, we observed that the serum albumin level of the patients during their admission to the emergency department did not have an impact on the development of CIN. The serum albumin level was found to be lower in the patient group with CIN (+) than in the group with CIN (-). The average serum albumin level was found to be higher in females than males at the time of admission to the emergency department. In experimental studies, vacuolation is experienced in proximal tubular epithelial cells in the initial stages of CIN development, and this situation is more significant in females than males [10]. It is stated that being female is a risk factor for the development of CIN [7-8]. In the study, there was a significant difference between the groups in terms of gender distribution. The proportion of female patients was higher in the CIN (-) group, whereas the number of male patients was higher than the number of female patients in the CIN (+) group. Increasing serum creatinine levels in CKD increases the risk of developing CIN [4]. It was found in our study that being a male and having a high serum creatinine level increased the risk of being diagnosed with CIN approximately one-fold as compared to being a female patient and having a low serum creatinine level. This may be due to the high serum creatinine levels and because the patients CIN $(+)$ were mostly male.

Mehran et al. stated that age over 75 is an independent and determinant factor of the development of CIN [2]. Although there was no statistically significant difference between the two groups in terms of age in our study, the average age of the patients with CIN (+) was found to be $74.27 \pm 12.19$. Being a female and being older increase the risk of being diagnosed with CIN approximately one-fold as compared to the males and being younger. This finding correlates with the related research in the literature $[2,8]$. 


\section{Conclusions}

In conclusion, in addition to serum creatinine and albumin levels, age and gender parameters should also be considered in terms of the risk of CIN development in the patients admitted to the emergency department and given a contrast agent. To summarize: (a) Being a male patient and having a high serum creatinine level increases the risk of being diagnosed with CIN approximately one-fold as compared to being a female patient and having a low serum creatinine level (Exp $[\mathrm{B}]=1.148)$; (b) Being a female patient and being older increases the risk of being diagnosed with CIN approximately one-fold as compared to being male and being at a younger age $(\operatorname{Exp}[\mathrm{B}]=1.113)$; (c) Being a female patient and having a high pre-contrast serum albumin level increases the risk of being diagnosed with CIN nearly four times as compared to being a male and having a low pre-contrast serum albumin level (Exp $[B]=4.362)$; (d) Serum creatinine levels at the admission stage are determinant of the development of CIN; (e) Serum albumin levels at the time of admission to the emergency department have no impact on the development of CIN.

\section{Additional Information \\ Disclosures}

Human subjects: Consent was obtained by all participants in this study. Çanakkale Onsekiz Mart University, Clinical Research Ethical Committee issued approval 2020-09. T.C. ÇANAKKALE ONSEKİZ MART ÜNIVERSITESİ REKTÖRLÜĞÜ Klinik Araştırmalar Etik Kurulu Sayı : 18920478-050.01.04-E.2000087904 03/07/2020 Konu : Başvuru İncelemesi(Dr. Öğr.Üyesi Canan AKMAN) Sayın Dr. Öğr. Üyesi Canan AKMAN Yürütücülüğünü yapmış olduğunuz "Acil Servise Gelen Hastalarda Kontrast Nefropatisi Sıklığı" başlıklı 2011KAEK-27/2020-E.2000075168 nolu projeniz ile ilgili olarak Klinik Araştırmalar Etik Kurulunun almış olduğu 01.07.2020 tarih ve 24-09 nolu kararı aşağıdadır. Bilgilerinize rica ederim. Karar Tarihi:01.07.2020 Karar No :2020-09 Karar-24) 2011-KAEK-27/2020-E.2000075168 no'lu araştırma ile ilgili olarak, Proje yürütücüsü Dr. Öğr.Üyesi Canan AKMAN'nın çalışması Etik Kurul tarafından değerlendirilmiş olup; yapılan oylamada "ETİK KURUL ONAYINI ALIR" kararı verilmiştir. Prof. Dr. Coşkun SILAN Kurul Başkanı. Animal subjects: All authors have confirmed that this study did not involve animal subjects or tissue. Conflicts of interest: In compliance with the ICMJE uniform disclosure form, all authors declare the following: Payment/services info: All authors have declared that no financial support was received from any organization for the submitted work. Financial relationships: All authors have declared that they have no financial relationships at present or within the previous three years with any organizations that might have an interest in the submitted work. Other relationships: All authors have declared that there are no other relationships or activities that could appear to have influenced the submitted work.

\section{References}

1. Persson PB, Hansel P, Liss P: Pathophysiology of contrast medium-induced nephropathy. Kidney Int. 2005, 68:14-22. 10.1111/j.1523-1755.2005.00377.x

2. Mehran R, Aymong ED, Nikolsky E, et al.: A simple risk score for prediction of contrast-induced nephropathy after percutaneous coronary intervention: development and initial validation. J Am Coll Cardiol. 2004, 44:1393-1399. 10.1016/j.jacc.2004.06.068

3. Hou SH, Bushinsky DA, Wish JB, Cohen JJ, Harrington JT: Hospital-acquired renal insufficiency: a prospective study. Am J Med. 1983, 74:243-248. 10.1016/0002-9343(83)90618-6

4. McCullough PA, Choi JP, Feghali GA, SchusslerJM, Stoler RM, Vallabahn RC, Mehta A: Contrast-induced acute kidney injury. J Am Coll Cardiol. 2016, 68:1465-1473. 10.1016/j.jacc.2016.05.099

5. Hassan K, Fadi H: Is hypoalbuminemia a prognostic risk factor for contrast-induced nephropathy in peritoneal dialysis patients?. Ther Clin Risk Manag. 2014, 10:787-795. 10.2147/TCRM.S70665

6. Banda J, Duarte R, Dickens C, et al.: Risk factors and outcomes of contrast-induced nephropathy in hospitalised South Africans. S Afr Med J. 2016, 106:699-703. 10.7196/SAMJ.2016.v106i7.10429

7. Ghani AA, Tohamy KY: Risk score for contrast induced nephropathy following percutaneous coronary intervention. Saudi J Kidney Dis Transpl. 2009, 20:240-245.

8. Mohammed NM, Mahfouz A, Achkar K, Rafie IM, Hajar R: Contrast-induced nephropathy. Heart Views. 2013, 14:106-116.

9. Rundback JH, Nahl D, Yoo V: Contrast-induced nephropathy. J Vasc Surg. 2011, 54:575-579. 10.1016/j.jvs.2011.04.047

10. Carraro-Eduardo JC, Santıno MFF, Macedo HW, da Sılva LE: Impact of gender in early structural changes of contrast induced nephropathy in rats. J Bras Nefrol. 2016, 38:390-395. 10.5935/0101-2800.20160063 